\title{
The porcine respiratory microbiome: recent insights and future challenges
}

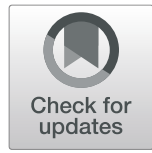

Mattia Pirolo ${ }^{1,2}$, Carmen Espinosa-Gongora', Debby Bogaert ${ }^{3}$ and Luca Guardabassi ${ }^{1,4^{*}}$ (D)

\begin{abstract}
Understanding the structure of the respiratory microbiome and its complex interactions with opportunistic pathogenic bacteria has become a topic of great scientific and economic interest in livestock production, given the severe consequences of respiratory disease on animal health and welfare. The present review focuses on the microbial structures of the porcine upper and lower airways, and the factors that influence microbiome development and onset of respiratory disease. Following a literature search on PubMed and Scopus, 21 articles were selected based on defined exclusion criteria (20 studies performed by $16 \mathrm{~S}$ rRNA gene sequencing and one by shotgun metagenomics). Analysis of the selected literature indicated that the microbial structure of the upper respiratory tract undergoes a remarkable evolution after birth and tends to stabilise around weaning. Antimicrobial treatment, gaseous ammonia concentration, diet and floor type are amongst the recognized environmental factors influencing microbiome structure. The predominant phyla of the upper respiratory tract are Proteobacteria and Firmicutes with significant differences at the genus level between the nasal and the oropharyngeal cavity. Only five studies investigated the lower respiratory tract and their results diverged in relation to the relative abundance of these two phyla and even more in the composition of the lung microbiome at the genus level, likely because of methodological differences. Reduced diversity and imbalanced microbial composition are associated with an increased risk of respiratory disease. However, most studies presented methodological pitfalls concerning specimen collection, sequencing target and depth, and lack of quality control. Standardization of sampling and sequencing procedures would contribute to a better understanding of the structure of the microbiota inhabiting the lower respiratory tract and its relationship with pig health and disease.
\end{abstract}

Keywords: Pig, Microbiota, Respiratory tract, Health, Disease, Porcine respiratory disease complex

\section{Background}

The development of culture-independent approaches has helped to overcome the limitations of microbial cultivation, unveiling a completely new (micro) universe. Compared to culture-based approaches, metagenomic analysis, i.e. the examination of genomes and genes present in a host or environmental sample, provides a deeper understanding of microbial composition and

\footnotetext{
* Correspondence: Ig@sund.ku.dk; Iguardabassi@rvc.ac.uk

'Department of Veterinary and Animal Sciences, University of Copenhagen, Frederiksberg, Denmark

${ }^{4}$ Department of Pathobiology \& Population Sciences, Royal Veterinary College, United Kingdom, Hawkhead Lane, North Mymms, Hatfield, Herts AL9 7TA, UK

Full list of author information is available at the end of the article
}

function. Nowadays, it is possible to appreciate the diversity of bacterial communities thanks to the availability of high-throughput next-generation sequencing (NGS) methods and new advancements in bioinformatics. Sequencing of one or more of the hypervariable regions of the 16S rRNA gene (targeted NGS analysis), and shotgun sequencing of the total DNA present in a sample (untargeted NGS analysis) are the two main methods for microbiome research [1]. Early microbiome studies mostly focused on bacterial composition in the gastrointestinal tract and its influence on host health and disease [2-4]. Recent studies investigating the bacterial topography of the respiratory tract in humans [5] and animals [6] have revealed high microbial richness and diversity in the upper respiratory tract (URT) and

(c) The Author(s). 2021 Open Access This article is licensed under a Creative Commons Attribution 4.0 International License, which permits use, sharing, adaptation, distribution and reproduction in any medium or format, as long as you give appropriate credit to the original author(s) and the source, provide a link to the Creative Commons licence, and indicate if changes were made. The images or other third party material in this article are included in the article's Creative Commons licence, unless indicated otherwise in a credit line to the material. If material is not included in the article's Creative Commons licence and your intended use is not permitted by statutory regulation or exceeds the permitted use, you will need to obtain permission directly from the copyright holder. To view a copy of this licence, visit http://creativecommons.org/licenses/by/4.0/. 
surprisingly even in the lower respiratory tract (LRT), upending the historical notion that lungs are sterile. Consequently, there is growing interest in determining the role of the respiratory microbiome in health and disease.

Porcine Respiratory Disease Complex (PRDC) is a multi-factorial, polymicrobial respiratory disease that is generally trigged by stress factors associated with intensive farm production (e.g. overcrowding, group mixing, improper ventilation and overheating or chilling temperature) and viral pathogens, such as swine influenza virus (swIAV), porcine reproductive and respiratory syndrome virus (PRRSV) and porcine circovirus type 2 (PCV2) [7]. This disease complex is a major cause of morbidity and mortality in pig production [8] resulting in significant economic losses, treatment costs, increased antimicrobial consumption, reduced growth rates and low feed conversion efficiency [9]. The prevalence of lung lesions in slaughter pigs has been estimated to be as high as $60-65 \%$, indicating that roughly two out of three pigs in the European Union food chain are affected by PRDC [8]. In the United States, PRDC accounted for the majority of all nursery and grower/finisher pig deaths (47.3 and $75.1 \%$, respectively) in 2012 [10]. The bacterial species involved in this disease complex are traditionally distinguished between primary (e.g. Mycoplasma hyopneumoniae, Actinobacillus pleuropneumoniae and Bordetella bronchiseptica) and secondary pathogens (e.g. Pasteurella multocida, Haemophilus parasuis and Streptococcus suis) [11]. As some of these species are also normal commensals of the URT in healthy pigs though simultaneously cause enzootic pneumonia worldwide [12], understanding the complex interactions between the microbiome of the URT and LRT has become a topic of great scientific interest with potential impact on animal welfare and farm economy.

The role of the porcine gastrointestinal microbiome in respiratory disease has been previously reviewed by Niederwerder (2017), with particular emphasis on how the gastrointestinal microbiome impacts pig development and influences respiratory disease onset [13]. Here, we reviewed the current knowledge of the porcine respiratory microbiome and provided updated studies investigating its composition and development at different sites. Since little information is available on the role of viruses, phages, and fungi in the porcine respiratory microbiome, the goal of this review was to provide an overview of the bacterial topography of the healthy pig respiratory tract and how changes in the microbial community composition may be positively or negatively correlated to disease occurrence based on the current scientific evidence. At the same time, we identified and discussed methodological pitfalls of respiratory microbiome studies with reference to this animal species.

\section{Literature search}

A literature search in the PubMed and Scopus databases was started on August 1, 2019 and ended on September 30, 2020. Relevant peer-reviewed publications were searched applying the following search criterion: (porcine OR pig OR swine) AND (microbiome OR microbiota) AND (pulmonary OR lung OR respiratory OR nasal OR oropharyngeal OR tonsil). A flow chart illustrating the selection strategy is shown in Fig. 1. Four exclusion criteria were applied: $i$ ) studies where the microbiome composition does not refer to the respiratory tract, ii) studies using exclusively culture-based methods, iii) studies in languages other than English, and $i v$ ) reviews.

Out of 204 records identified through database searching (94 in PubMed and 110 in Scopus), 117 nonduplicate articles were screened, and 21 eligible papers were selected based on the exclusion criteria. The main features of the eligible studies are summarized in Table 1. All but one article (95.2\%) included 16S-based metataxonomic data, with the remaining study $(4.8 \%)$ evaluating the microbiome composition through shotgun metagenomics. The microbiota composition of the URT was assessed in 16 studies (76.2\%). Only five studies (23.8\%) focused on the LRT microbiome.

\section{Initial colonization and development of the respiratory tract microbiome}

The pig respiratory tract can be divided into two parts, the URT, consisting of the nose, pharynx, larynx, and the LRT, which comprises the trachea and lungs [14]. The anatomical development of the structures of the porcine respiratory tract is a complex multistage process that begins at the embryonal stage, with the formation of the olfactory placodes, the laryngotracheal groove and the lung buds, and continues after birth, with the ventral scroll bone development and the progression of alveolar formation [15]. The origin of the first bacteria colonizing the airways in new-born piglets remains unclear. According to the sterile womb paradigm in humans, bacteria are acquired from both the mother (vertical acquisition) and the environment (horizontal acquisition) during and shortly after birth [16]. However, airway colonization might begin in utero, likely during intraamniotic infection (chorioamnionitis), though studies are needed to confirm this hypothesis in pigs. Regardless of when microbial colonization starts, either in utero or postnatally, all external and internal surfaces of newborns become heavily colonized afterbirth. Wang et al. (2013) showed that microbial development of the piglet nasal microbiota is strongly shaped by external factors, such as delivery mode and feeding type [17].

The tonsillar microbiota of piglets within the first 8 hours after birth resembles the sow vaginal and teat skin 


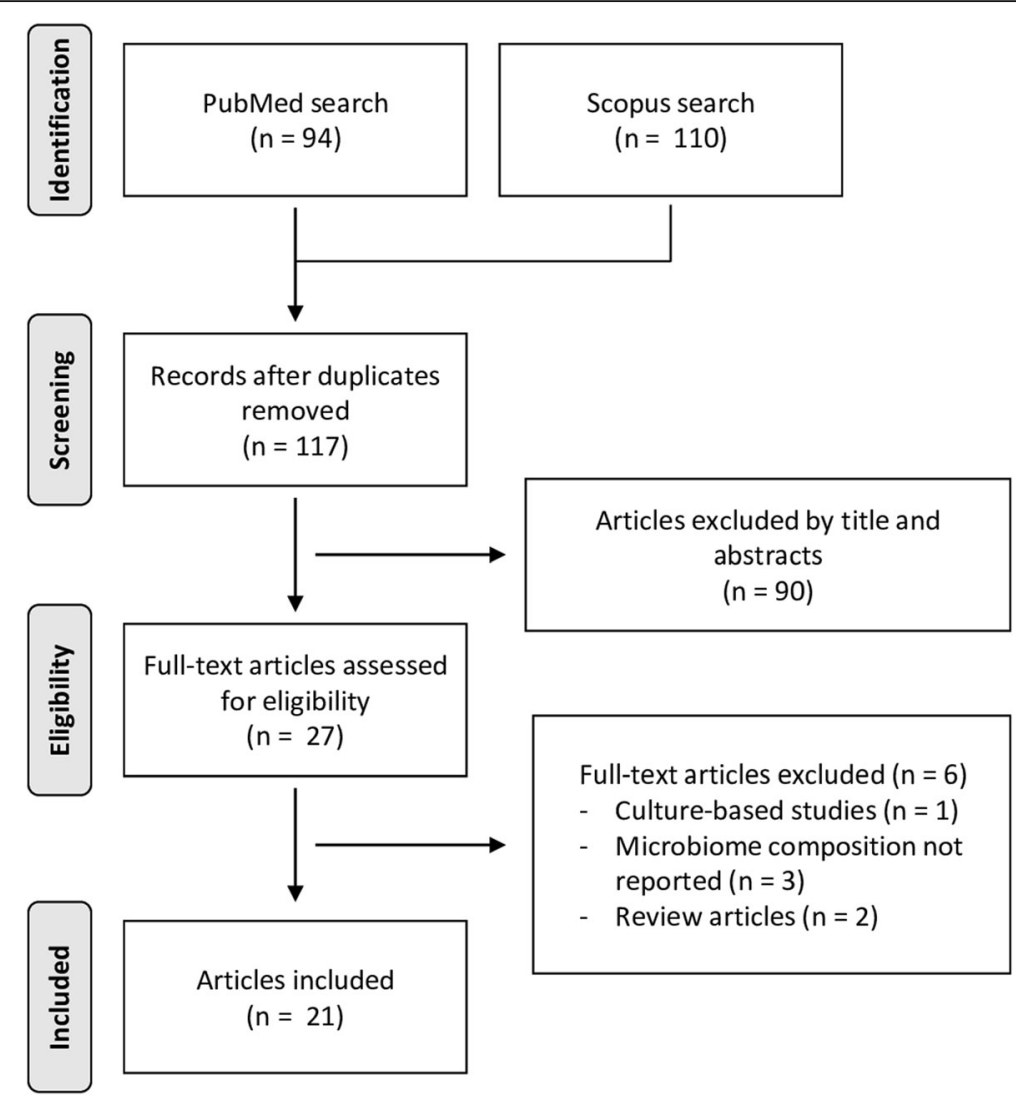

Fig. 1 Flowchart of the literature search and studies selection

microbiota, indicating that these two body sites represent an important source for early colonization of the URT [18]. Similarly, the bacterial species detectable in the URT of infants during the first few hours of life resemble those occurring in the mother's vaginal or skin microbiota depending on whether the child is born by natural birth or C-section, respectively $[19,20]$. A longitudinal study by Slifierz et al. (2015) showed remarkable changes in the composition and structure of the nasal microbiota of piglets during the first 7 weeks after birth, which tended to stabilise after two-to-three weeks postweaning [21]. Another study indicated that the microbial communities of tonsils of healthy piglets initially clustered by litter, but then converged by 3 weeks of age, regardless of litter or housing [18]. While the influences of environmental exposures on the respiratory microbiome composition in pigs are generally known, the degree to which host genetics plays a role in structuring the airway microbial community is less well understood.

Weaning has a pivotal influence on the early microbiome composition of piglets [13]. Major microbial shifts occur in response to the transition to solid-feed in the gut microbiome of healthy suckling piglets [22]. This holds true also for the URT microbiome, as weaning has been associated with an increase in the relative abundance of Streptococcaceae and a decrease of Moraxellaceae abundance; this might be result of changes in feed, but also in housing conditions and antimicrobial exposure $[18,23]$. Feeding strategies and the flooring system have been proposed to impact the composition of the URT respiratory microbiome [24, 25]. Significant differences in the relative abundance of some genera, including Macrococcus, Pseudomonas, Corynebacterium and Fibrobacter, have been reported in the nasal microbiota of liquid-fed pigs compared with conventional diet fed pigs [24]. Simple-slatted systems were proposed by Megahet et al. (2019) to provide better conditions for the establishment and development of a balanced respiratory and intestinal microbiota compared to strawbased rearing systems. The authors hypothesized that harmful taxa could prevail in complex environments and might decrease the opportunity for beneficial bacteria to flourish, which may impede the amplification of microbial diversity [25].

Ammonia emissions are known for their potential negative consequences on farming environments, the ecosystem, and human and animal health [26]. The concentration of gaseous ammonia in the farm environment 
Table 1 Summary of studies on the porcine respiratory microbiota

\begin{tabular}{|c|c|c|c|c|c|c|c|c|}
\hline \multicolumn{2}{|l|}{ Study population } & \multicolumn{2}{|l|}{ Sampling } & \multirow{2}{*}{$\begin{array}{l}\text { Positive and } \\
\text { negative } \\
\text { sequencing } \\
\text { controls }\end{array}$} & \multirow{2}{*}{$\begin{array}{l}\text { Sequencing } \\
\text { platform (16S } \\
\text { rRNA gene } \\
\text { region) }\end{array}$} & \multirow{2}{*}{$\begin{array}{l}\text { Data } \\
\text { processing } \\
\text { software } \\
\text { (reference } \\
\text { database) }\end{array}$} & \multirow[t]{2}{*}{ Main finding } & \multirow[t]{2}{*}{ Reference } \\
\hline No. of animals & $\begin{array}{l}\text { Age of } \\
\text { animals }\end{array}$ & $\begin{array}{l}\text { Respiratory } \\
\text { tract }\end{array}$ & Sample type & & & & & \\
\hline \multicolumn{9}{|c|}{ Microbiome development } \\
\hline $\begin{array}{l}10 \text { Yorkshire- } \\
\text { Landrace pigs }\end{array}$ & $0-7$ weeks & URT & Nasal swab & Absent & $\begin{array}{l}\text { Illumina MiSeq } \\
\text { (V4) }\end{array}$ & mothur (RDP) & $\begin{array}{l}\text { The nasal } \\
\text { microbiota of pigs } \\
\text { undergoes a } \\
\text { remarkable } \\
\text { evolution during } \\
\text { the first } 7 \text { weeks } \\
\text { of life }\end{array}$ & 21 \\
\hline 34 piglets & $0-4$ weeks & URT & Tonsil swab & $\begin{array}{l}\text { Extraction } \\
\text { control, } \\
\text { Escherichia coli } \\
\text { DH5a genomic } \\
\text { control and } \\
\text { mock } \\
\text { community } \\
\text { DNA }\end{array}$ & $\begin{array}{l}\text { Illumina MiSeq } \\
\text { (V4) }\end{array}$ & mothur (SILVA) & $\begin{array}{l}\text { The tonsillar } \\
\text { microbiome of } \\
\text { piglets does not } \\
\text { show } \\
\text { composition } \\
\text { stability until } 3 \\
\text { weeks, and shared } \\
\text { similarities with } \\
\text { the sow vaginal } \\
\text { and teat skin } \\
\text { microbiome }\end{array}$ & 18 \\
\hline 16 piglets & 0-19 weeks & URT & Tonsil swab & $\begin{array}{l}\text { Extraction } \\
\text { control }\end{array}$ & $\begin{array}{l}\text { Illumina MiSeq } \\
\text { (V4) }\end{array}$ & mothur (SILVA) & $\begin{array}{l}\text { Significant } \\
\text { community shifts } \\
\text { during the } \\
\text { development of } \\
\text { the tonsillar } \\
\text { microbiome are } \\
\text { correlated with } \\
\text { disruption events, } \\
\text { including } \\
\text { weaning, changes } \\
\text { in feed, antibiotic } \\
\text { treatment, and } \\
\text { movement to } \\
\text { new housing }\end{array}$ & 23 \\
\hline \multicolumn{9}{|c|}{ Bacterial topography in healthy animals } \\
\hline $\begin{array}{l}8 \text { pigs from a } \\
\text { herd with } \\
\text { health status } \\
\text { and } 4 \text { pigs } \\
\text { from a healthy } \\
\text { herd with a } \\
\text { history of } \\
\text { chronic } \\
\text { respiratory } \\
\text { problems }\end{array}$ & $\begin{array}{l}18-20 \\
\text { weeks }\end{array}$ & URT & $\begin{array}{l}\text { Tonsil swab } \\
\text { and tissue }\end{array}$ & Absent & $\begin{array}{l}\text { GS } 454 \text { FLX- } \\
\text { Titanium (full- } \\
\text { length 16S } \\
\text { rRNA gene) }\end{array}$ & $\begin{array}{l}\text { RDP } \\
\text { pyrosequencing } \\
\text { pipeline (RDP) }\end{array}$ & $\begin{array}{l}\text { Actinobacillus, } \\
\text { Pasteurella and } \\
\text { Haemophilus form } \\
\text { the tonsillar core } \\
\text { microbiome }\end{array}$ & 38 \\
\hline $\begin{array}{l}5 \text { MRSA- } \\
\text { positive and } 8 \\
\text { MRSA-negative } \\
\text { pigs from a } \\
\text { farm that used } \\
\text { a liquid feeding } \\
\text { system and } 7 \\
\text { MRSA-negative } \\
\text { pigs from a } \\
\text { farm that used } \\
\text { conventional } \\
\text { feeding } \\
\text { practices }\end{array}$ & $\begin{array}{l}1-2 \text { weeks } \\
\text { prior to } \\
\text { slaughter }\end{array}$ & URT & Nasal swab & Absent & $\begin{array}{l}\text { Illumina MiSeq } \\
\text { (V4) }\end{array}$ & mothur (Silva) & $\begin{array}{l}\text { The nasal cavity } \\
\text { of slaughter-age } \\
\text { pigs harbours a } \\
\text { rich and diverse } \\
\text { microbial commu- } \\
\text { nity that can be } \\
\text { influenced by diet } \\
\text { and farm man- } \\
\text { agement practices }\end{array}$ & 24 \\
\hline $\begin{array}{l}100 \text { pigs } \\
\text { classified as S. } \\
\text { aureus carriers }\end{array}$ & $\begin{array}{l}\text { Last } 3 \text { week } \\
\text { of } \\
\text { production }\end{array}$ & URT & Nasal swab & Absent & $\begin{array}{l}\text { GS } 454 \text { FLX } \\
\text { Titanium (V3- } \\
\text { V5) }\end{array}$ & $\begin{array}{l}\text { BION-meta } \\
\text { (RDP) }\end{array}$ & $\begin{array}{l}\text { The nasal } \\
\text { microbiota may } \\
\text { play a role in the }\end{array}$ & 36 \\
\hline
\end{tabular}


Table 1 Summary of studies on the porcine respiratory microbiota (Continued)

\begin{tabular}{|c|c|c|c|c|c|c|c|c|}
\hline \multicolumn{2}{|l|}{ Study population } & \multicolumn{2}{|l|}{ Sampling } & \multirow{2}{*}{$\begin{array}{l}\text { Positive and } \\
\text { negative } \\
\text { sequencing } \\
\text { controls }\end{array}$} & \multirow{2}{*}{$\begin{array}{l}\text { Sequencing } \\
\text { platform (16S } \\
\text { rRNA gene } \\
\text { region) }\end{array}$} & \multirow{2}{*}{$\begin{array}{l}\text { Data } \\
\text { processing } \\
\text { software } \\
\text { (reference } \\
\text { database) }\end{array}$} & \multirow[t]{2}{*}{ Main finding } & \multirow[t]{2}{*}{ Reference } \\
\hline No. of animals & $\begin{array}{l}\text { Age of } \\
\text { animals }\end{array}$ & $\begin{array}{l}\text { Respiratory } \\
\text { tract }\end{array}$ & Sample type & & & & & \\
\hline $\begin{array}{l}(n=44) \text { and } \\
\text { non-carriers } \\
(n=56)\end{array}$ & cycle & & & & & & $\begin{array}{l}\text { individual } \\
\text { predisposition to } \\
\text { S. aureus nasal } \\
\text { carriage in pigs }\end{array}$ & \\
\hline 6 pigs & $\begin{array}{l}\text { Not } \\
\text { specified }\end{array}$ & URT & $\begin{array}{l}\text { Swabs and } \\
\text { biopsies of true } \\
\text { and false vocal } \\
\text { folds of } \\
\text { larynges }\end{array}$ & $\begin{array}{l}\text { Extraction and } \\
\text { PCR controls }\end{array}$ & $\begin{array}{l}\text { GS } 454 \text { FLX- } \\
\text { Titanium (V3- } \\
\text { V5) }\end{array}$ & mothur (SILVA) & $\begin{array}{l}\text { There is no } \\
\text { difference in } \\
\text { laryngeal } \\
\text { microbial } \\
\text { communities } \\
\text { when sampled via } \\
\text { swab or biopsy } \\
\text { from either the } \\
\text { true or false vocal } \\
\text { fold }\end{array}$ & 42 \\
\hline $\begin{array}{l}\text { Two lavage } \\
\text { pools from } 20 \\
\text { lungs } \\
\text { presenting } \\
\text { enzootic } \\
\text { pneumonia } \\
\text { signs and } 20 \\
\text { lungs without } \\
\text { macroscopic } \\
\text { pneumonia } \\
\text { signs }\end{array}$ & $\begin{array}{l}\text { Not } \\
\text { specified }\end{array}$ & LRT & BAL & Absent & $\begin{array}{l}\text { GS } 454 \text { FLX } \\
\text { Titanium } \\
\text { (shotgun } \\
\text { metagenomics) }\end{array}$ & $\begin{array}{l}\text { MG-RAST } \\
\text { (M5NR) }\end{array}$ & $\begin{array}{l}\text { In farms with a } \\
\text { history of chronic } \\
\text { respiratory } \\
\text { problems, } \\
\text { Mycoplasma } \\
\text { hyopneumoniae is } \\
\text { present in lungs } \\
\text { with or without } \\
\text { enzootic } \\
\text { pneumonia signs }\end{array}$ & 46 \\
\hline $\begin{array}{l}20 \text { lungs from } \\
\text { the six- } \\
\text { generation off- } \\
\text { spring of a } \\
\text { population } \\
\text { crossed by } \\
\text { eight pig } \\
\text { breeds (seven } \\
\text { healthy, six and } \\
\text { seven with } \\
\text { moderate or } \\
\text { severe lesion, } \\
\text { respectively) }\end{array}$ & $\begin{array}{l}240 \pm 3 \\
\text { days }\end{array}$ & LRT & BAL & $\begin{array}{l}\text { Extraction and } \\
\text { PCR controls }\end{array}$ & $\begin{array}{l}\text { Illumina MiSeq } \\
\text { (V3-V4) }\end{array}$ & $\begin{array}{l}\text { QIIME } \\
\text { (Greengenes) }\end{array}$ & $\begin{array}{l}\text { Reduced } \\
\text { microbial diversity } \\
\text { but more biomass } \\
\text { was observed in } \\
\text { severe-lesion } \\
\text { lungs compared } \\
\text { to healthy lungs }\end{array}$ & 43 \\
\hline $\begin{array}{l}20 \text { Duroc- } \\
\text { Landrace- } \\
\text { Yorkshire } \\
\text { piglets (10 } \\
\text { PRRSV- } \\
\text { challenged and } \\
10 \text { controls) }\end{array}$ & $8-10$ weeks & LRT & BAL & Absent & $\begin{array}{l}\text { Illumina MiSeq } \\
\text { (V3-V4) }\end{array}$ & mothur (SILVA) & $\begin{array}{l}\text { Challenging pigs } \\
\text { with the PRRSV } \\
\text { increase the } \\
\text { presence in the } \\
\text { lungs of } \\
\text { opportunistic } \\
\text { pathogens, } \\
\text { including } \\
\text { Haemophilus } \\
\text { parasuis and } \\
\text { Mycoplasma } \\
\text { hyorhinis }\end{array}$ & 45 \\
\hline \multicolumn{9}{|c|}{ Microbiome relationship with disease and productivity } \\
\hline $\begin{array}{l}100 \text { piglets } \\
\text { from } 4 \text { farms } \\
\text { with Glässer's } \\
\text { disease } \\
\text { outbreaks and } \\
\text { from } 6 \text { control } \\
\text { farms (10 } \\
\text { piglets/farms) }\end{array}$ & $\begin{array}{l}3-4 \text { weeks } \\
\text { before } \\
\text { weaning }\end{array}$ & URT & Nasal swab & Absent & $\begin{array}{l}\text { Illumina MiSeq } \\
\text { (V3-V4) }\end{array}$ & $\begin{array}{l}\text { QIIME } \\
\text { (Greengenes) }\end{array}$ & $\begin{array}{l}\text { The nasal } \\
\text { microbiota of } \\
\text { piglets is } \\
\text { associated to the } \\
\text { clinical status of } \\
\text { the farm, leading } \\
\text { to different } \\
\text { susceptibilities to } \\
\text { invasive infection } \\
\text { by opportunistic }\end{array}$ & 35 \\
\hline
\end{tabular}


Table 1 Summary of studies on the porcine respiratory microbiota (Continued)

\begin{tabular}{|c|c|c|c|c|c|c|c|c|}
\hline \multicolumn{2}{|l|}{ Study population } & \multicolumn{2}{|l|}{ Sampling } & \multirow{2}{*}{$\begin{array}{l}\text { Positive and } \\
\text { negative } \\
\text { sequencing } \\
\text { controls }\end{array}$} & \multirow{2}{*}{$\begin{array}{l}\text { Sequencing } \\
\text { platform (16S } \\
\text { rRNA gene } \\
\text { region) }\end{array}$} & \multirow{2}{*}{$\begin{array}{l}\text { Data } \\
\text { processing } \\
\text { software } \\
\text { (reference } \\
\text { database) }\end{array}$} & \multirow[t]{2}{*}{ Main finding } & \multirow[t]{2}{*}{ Reference } \\
\hline No. of animals & $\begin{array}{l}\text { Age of } \\
\text { animals }\end{array}$ & $\begin{array}{l}\text { Respiratory } \\
\text { tract }\end{array}$ & Sample type & & & & & \\
\hline & & & & & & & pathogens & \\
\hline 30 pigs & $\begin{array}{l}\text { Not } \\
\text { specified }\end{array}$ & URT & Nasal swab & $\begin{array}{l}\text { Extraction } \\
\text { control, PCR } \\
\text { control and } \\
\text { Staphylococcus } \\
\text { mock } \\
\text { community }\end{array}$ & $\begin{array}{l}\text { Illumina MiSeq } \\
\text { (V1-V2) }\end{array}$ & $\begin{array}{l}\text { BION-meta } \\
\text { (RDP) }\end{array}$ & $\begin{array}{l}\text { The MRSA nasal } \\
\text { colonization is } \\
\text { negatively } \\
\text { correlated with } \\
\text { the level of } \\
\text { Streptococcus }\end{array}$ & 37 \\
\hline $\begin{array}{l}33 \text { piglets ( } 23 \\
\text { diseased and } \\
10 \text { healthy) }\end{array}$ & 2-3 weeks & URT & $\begin{array}{l}\text { Oropharyngeal } \\
\text { swab }\end{array}$ & $\begin{array}{l}\text { Extraction } \\
\text { control }\end{array}$ & $\begin{array}{l}\text { Illumina MiSeq } \\
\text { (V3-V4) }\end{array}$ & $\begin{array}{l}\text { RDP Classifier } \\
\text { (SILVA) }\end{array}$ & $\begin{array}{l}\text { Moraxella, } \\
\text { Veillonella, and } \\
\text { Porphyromonas } \\
\text { may play a } \\
\text { potential role in } \\
\text { PRDC and } \\
\text { Lactobacillus may } \\
\text { have a protective } \\
\text { role against } \\
\text { respiratory } \\
\text { diseases }\end{array}$ & 41 \\
\hline 0 piglets & 8 weeks & URT & Nasal swab & Absent & $\begin{array}{l}\text { Illumina MiSeq } \\
\text { (V1-V3) }\end{array}$ & $\begin{array}{l}\text { QIIME } \\
\text { (Greengenes) }\end{array}$ & $\begin{array}{l}\text { The impact of } \\
\text { parenteral } \\
\text { antibiotics on the } \\
\text { pig nasal } \\
\text { microbiota is } \\
\text { variable and } \\
\text { modulates the } \\
\text { nasal microbiota } \\
\text { structure }\end{array}$ & 29 \\
\hline $\begin{array}{l}31 \text { piglets } \\
\text { (based on the } \\
\text { BioSample } \\
\text { number in } \\
\text { NCBI Sequence } \\
\text { Read Archive) }\end{array}$ & 3/4-weeks & URT & Nasal swab & Absent & $\begin{array}{l}\text { Illumina MiSeq } \\
\text { (V3-V4) }\end{array}$ & QIIME (RDP) & $\begin{array}{l}\text { Removal of } \\
\text { perinatal } \\
\text { antimicrobials at } \\
\text { weaning increases } \\
\text { the bacterial } \\
\text { diversity in nasal } \\
\text { microbiota and } \\
\text { the relative } \\
\text { abundance of } \\
\text { beneficial genera }\end{array}$ & 31 \\
\hline 44 piglets & 6 weeks & URT & Tonsil surface & $\begin{array}{l}\text { Extraction } \\
\text { control and } \\
\text { mock } \\
\text { community }\end{array}$ & $\begin{array}{l}\text { Illumina MiSeq } \\
\text { (V4) }\end{array}$ & DADA2 (SILVA) & $\begin{array}{l}\text { Chlortetracycline } \\
\text { administration } \\
\text { enhances the } \\
\text { shedding and } \\
\text { colonization of } \\
\text { multidrug } \\
\text { resistant S. } \\
\text { Typhimurium in } \\
\text { pigs }\end{array}$ & 39 \\
\hline 65 piglets & $2-3$ weeks & URT & $\begin{array}{l}\text { Nasal swab } \\
\text { and tonsils } \\
\text { tissue }\end{array}$ & Absent & $\begin{array}{l}\text { Illumina MiSeq } \\
\text { (V4) }\end{array}$ & mothur (SILVA) & $\begin{array}{l}\text { Short-term } \\
\text { exposure to } \\
\text { broad-spectrum } \\
\text { antibiotics (oxy- } \\
\text { tetracycline) can } \\
\text { disturb the URT } \\
\text { microbiota }\end{array}$ & 30 \\
\hline $\begin{array}{l}120 \text { Duroc- } \\
\text { Landrace- } \\
\text { Yorkshire pigs } \\
\text { (the nasal } \\
\text { microbiota of } \\
72 \text { pigs was } \\
\text { analysed) }\end{array}$ & $\begin{array}{l}\text { Not } \\
\text { specified }\end{array}$ & URT & Nasal swab & Absent & $\begin{array}{l}\text { Illumina MiSeq } \\
\text { (V3-V4) }\end{array}$ & $\begin{array}{l}\text { QIIME } \\
\text { (Greengenes) }\end{array}$ & $\begin{array}{l}\text { Concentrations of } \\
\text { ammonia higher } \\
\text { than } 25 \text { ppm may } \\
\text { cause respiratory } \\
\text { damage and even } \\
\text { pneumonia by } \\
\text { affecting the }\end{array}$ & 26 \\
\hline
\end{tabular}


Table 1 Summary of studies on the porcine respiratory microbiota (Continued)

\begin{tabular}{|c|c|c|c|c|c|c|c|c|}
\hline \multicolumn{2}{|l|}{ Study population } & \multicolumn{2}{|l|}{ Sampling } & \multirow{2}{*}{$\begin{array}{l}\text { Positive and } \\
\text { negative } \\
\text { sequencing } \\
\text { controls }\end{array}$} & \multirow{2}{*}{$\begin{array}{l}\text { Sequencing } \\
\text { platform (16S } \\
\text { rRNA gene } \\
\text { region) }\end{array}$} & \multirow{2}{*}{$\begin{array}{l}\text { Data } \\
\text { processing } \\
\text { software } \\
\text { (reference } \\
\text { database) }\end{array}$} & \multirow[t]{2}{*}{ Main finding } & \multirow[t]{2}{*}{ Reference } \\
\hline No. of animals & $\begin{array}{l}\text { Age of } \\
\text { animals }\end{array}$ & $\begin{array}{l}\text { Respiratory } \\
\text { tract }\end{array}$ & Sample type & & & & & \\
\hline & & & & & & & $\begin{array}{l}\text { colonization rates } \\
\text { of harmful } \\
\text { bacteria and } \\
\text { beneficial bacteria }\end{array}$ & \\
\hline 175 piglets & 19-22 days & LRT & $\begin{array}{l}\text { Bronchial } \\
\text { mucosa }\end{array}$ & Absent & $\begin{array}{l}\text { Illumina MiSeq } \\
\text { (V3-V4) }\end{array}$ & QIIME (SILVA) & $\begin{array}{l}\text { Increasing the } \\
\text { physical } \\
\text { complexity of } \\
\text { rearing } \\
\text { environment } \\
\text { provides } \\
\text { suboptimal } \\
\text { conditions for } \\
\text { establishing a } \\
\text { healthy microbial } \\
\text { community in the } \\
\text { growing pigs }\end{array}$ & 25 \\
\hline 8 piglets & 1-7 weeks & URT & $\begin{array}{l}\text { Oropharyngeal } \\
\text { swab }\end{array}$ & $\begin{array}{l}\text { Extraction } \\
\text { control, PCR } \\
\text { control and } \\
\text { mock } \\
\text { community }\end{array}$ & $\begin{array}{l}\text { Illumina iSeq } \\
\text { (V4) }\end{array}$ & $\begin{array}{l}\text { QIIME } \\
\text { (Greengenes) }\end{array}$ & $\begin{array}{l}\text { The rate of } \\
\text { average daily gain } \\
\text { of piglets is } \\
\text { associated with a } \\
\text { characteristic } \\
\text { oropharyngeal } \\
\text { microbial } \\
\text { signature }\end{array}$ & 56 \\
\hline $\begin{array}{l}28 \text { Duroc- } \\
\text { Landrace- } \\
\text { Yorkshire pigs } \\
\text { (eight healthy } \\
\text { and } 20 \text { PRDC- } \\
\text { affected) }\end{array}$ & $\begin{array}{l}270 \pm 3 \\
\text { days }\end{array}$ & LRT & BAL & Absent & $\begin{array}{l}\text { Illumina MiSeq } \\
\text { (V3-V4) }\end{array}$ & Q\|ME (RDP) & $\begin{array}{l}\text { In PRDC-affected } \\
\text { pigs, the propor- } \\
\text { tion of harmful } \\
\text { genera increased, } \\
\text { and the richness } \\
\text { of beneficial gen- } \\
\text { era decreased }\end{array}$ & 44 \\
\hline
\end{tabular}

Abbreviations: BAL Bronchoalveolar lavage, $L R T$ Lower respiratory tract, PRDC Porcine respiratory disease complex, PRRSV Porcine reproductive and respiratory syndrome virus, RPD Ribosomal Database Project, URT Upper respiratory tract

has been shown to affect the porcine airway [27]. In vivo testing showed that an increase in ammonia levels, especially above $25 \mathrm{ppm}$, significantly damaged tracheal mucosa and alveoli, and decreased growth performance [26]. In addition, ammonia levels above $25 \mathrm{ppm}$ reduced the colonization of beneficial bacteria such as Lactobacillus and increased the number of Moraxella and Streptococcus species in the nasal cavities of exposed pigs [26].

Antimicrobial exposure is another key environmental factor that can affect the development of URT microbiome at early stages of life, especially because antimicrobials are widely used for control of post-weaning diarrhoea [28]. Antimicrobial treatment perturbs the URT microbiome homeostasis regardless of the drug used (tylosin, ceftiofur, tulathromycin, oxytetracycline or penicillin) and the administration route (in-feed, parenteral or intramuscular) $[29,30]$. The changes observed in the URT microbiota are however specific to each antimicrobial, in some instances leading to dramatic changes in the relative abundance of some bacterial taxa [29]. For instance, parenteral administration of ceftiofur, a broad-spectrum third-generation cephalosporin with activity against both Gram-positive and Gram-negative bacteria, was shown to increase the relative abundance of Clostridium, and to decrease the relative abundance of Moraxella, Streptococcus and Neisseria in the nasal microbiome of healthy pigs [29]. A similar pattern was observed after parenteral administration of the macrolide tulathromycin, whereas parenteral administration of oxytetracycline had a lower effect on the porcine nasal microbiome, as only minor changes in Clostridium and Streptococcus populations were observed [29]. The impact of oxytetracycline on the pig URT microbiome has also been addressed by Mou et al. (2019), who compared the tonsillar and nasal microbiota after in-feed or parenteral administration of oxytetracycline. Interestingly, oral administration resulted in a more pronounced decrease in the bacterial diversity and a relative increase of the genera Actinobacillus and Streptococcus [30]. In another 
study, removal of perinatal antimicrobial treatment was associated with increased bacterial diversity and relative abundance of Prevotella and Lactobacillus in the nasal microbiota at weaning [31].

No studies have examined the initial colonization and development of the LRT microbiome in pigs. Human studies indicate that bacterial colonization of lungs is the result of a dynamic equilibrium maintained by immigration (micro-aspiration of URT bacterial members and inhalation of ambient air) and elimination (cough, mucociliary clearance, and immune system activity) [5, 32]. The scenario of a self-sustaining LRT, which takes advantage of a mutualistic interrelationship with the URT, has been also proposed for cattle [33, 34]. No information is available on the relationship between the URT and LRT in pigs since all studies focused on either the URT or LRT. The following paragraph provides an overview of the current knowledge on the diversity and composition of the microbial community residing in different parts of the respiratory tract of healthy pigs.

\section{Bacterial topography of the healthy respiratory tract}

Proteobacteria and Firmicutes were consistently reported as the predominant phyla colonizing the nasal cavity of healthy pigs, irrespective of their age [21, 29, 35, 36] (Fig. 2). Bacteroidetes and Actinobacteria were also identified, although at lower prevalence $[21,29,35,36]$. At the genus level, Moraxella was the dominant genus more often reported in the nasal cavity of healthy pigs throughout all the phases of production cycle, followed by Streptococcus, Clostridium and Lactobacillus [21, 24, $29,31,35,37]$.

The pig URT microbiota composition has also been investigated by sampling the surface and deep tissue of the tonsils [38]. At the phylum level, the composition of the tonsillar microbiome of adult pigs resembled that of the nasal microbiota, with Proteobacteria and Firmicutes as the predominant taxa [38] (Fig. 2). However, in contrast to the nasal microbiota, Actinobacillus, Pasteurella and Haemophilus formed the tonsillar core microbiome (e.g. the most widespread taxa that are found in all samples) at the genus level, although member of the Veillonella and Peptostreptococcus were also identified [38, 39]. Unlike the nasal cavity, Moraxella was reported as a less frequent colonizer of the tonsils [38], in line with human studies [40]. The oropharyngeal microbial community of healthy piglets resembled that of the tonsils, with Streptococcus, Actinobacillus and Lactobacillus forming the core microbiome [41]. Streptococcus was also reported as a common coloniser of the larynx of healthy finishing pigs [42], although discrimination at the species level between commensal and pathogenic streptococci (i.e. S. suis) was not possible due to lack of a deep metagenomic analysis.

We only identified four studies investigating the LRT microbiota composition in healthy pigs by $16 \mathrm{~S}$ rRNA gene sequencing (Table 1), and their results often diverged. Two studies reported Proteobacteria and Firmicutes as the main phyla, but the third most dominant

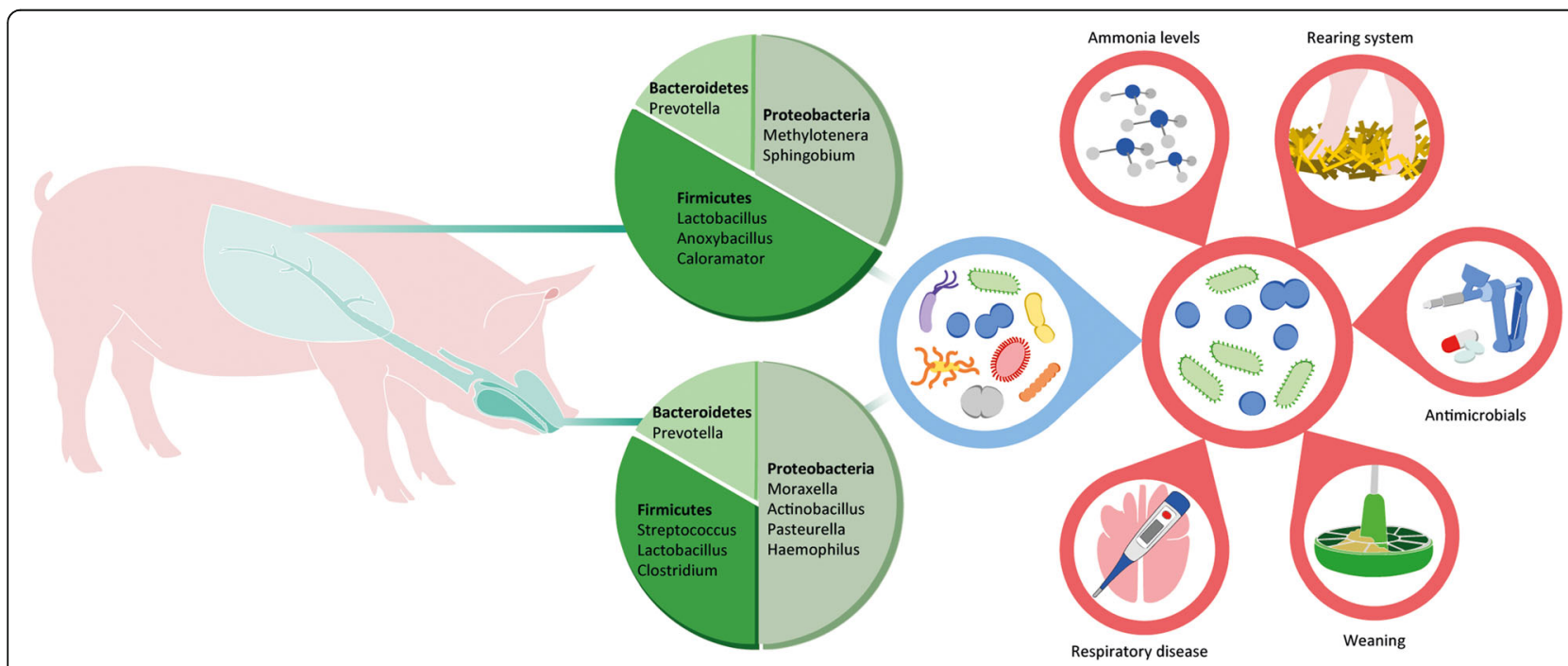

Fig. 2 Bacterial topography and factors shaping the porcine respiratory microbiome. The porcine respiratory microbiome is divided into the URT (upper pie chart) and the LRT (lower pie chart), which are mainly colonized by members of the Proteobacteria, Firmicutes, and Bacteroidetes. Under physiological conditions, the respiratory tract hosts a rich and diverse microbial community (left circle). Several factors, including respiratory disease onset, farm management practices and antimicrobial treatment, contribute to reducing the bacterial diversity in the imbalance state (right circle) 
phylum was Bacteroidetes in the study by Huang et al. (2019) and Tenericutes in the study by Li et al. (2020) [43, 44]. Conversely, Jiang et al. (2019) found Firmicutes as the dominant phylum, whereas Proteobacteria and Bacteroidetes formed only a minor portion of the healthy lung microbiota [45]. Even bigger differences were observed at the genus level, with the predominant genera being Methylotenera, Prevotella, Sphingobium and Lactobacillus according to Huang et al. (2019), Escherichia, Mycoplasma, Lactococcus and Macrococcus according to Li et al. (2020), and Anoxybacillus and Caloramator according to Jiang et al. (2019) [43-45]. The discrepancies between the three studies could be due to age disparities in the studied animals, and to methodological differences in sampling and data analysis (Table 1). The breeding environment could also have contributed to such discrepancies, given that in one study animals were housed in separate units in a biosafety level 2 (BSL2) facility [45], whereas animals were raised under natural conditions in the other two studies [43, 44]. In addition, two studies failed to include negative and positive control samples [44, 45], and some of the genera identified (e.g. Sphingobium and Escherichia) could be potential contaminants, especially in low biomass samples (see Section Methodological study limitations).

Bacterial composition at the phylum and genus level were not reported in another study that characterized the LRT microbiome by shotgun sequencing [46]. That study reported Mycoplasmataceae, Bradyrhizobiaceae and Flavobacteriaceae as the most abundant families in pooled bronchoalveolar lavage (BAL) samples from healthy pig lungs, with M. hyopneumoniae, Bradyrhizobium japonicum and Flavobacterium johnsoniae as the predominant species. Fungal and viral communities are known interact with members of the bacterial microbiome in humans [32]. To date, the porcine airway mycobiome has not been investigated, whereas the virome residing in the porcine airways has been evaluated by only two studies focused on the URT $[47,48]$. Results of both studies converge towards a complexity of viral communities in the pig upper airways $[47,48]$.

\section{Relationship of the respiratory microbiome with disease}

Changes in microbial community composition and alteration to the abundance and diversity of the airway microbiome are associated with the impairment of the host's health $[35,49,50]$. The loss of a stable ecosystem (homeostatic healthy state), which is resistant to colonization by pathogens, favours the progression towards an unstable community (i.e. dysbiosis) that is predisposed to infection and inflammation (pre-disease state) [51]. The decline towards the pre-disease state in the respiratory system, is often accompanied by unfavourable events, including partial loss of mucosal barrier, colonization by opportunistic pathogens and release of proinflammatory cytokines, which ultimately lead to the disease state [51].

The relationship between the respiratory microbiota and PRDC was evaluated by two recent studies comparing healthy and diseased pigs [41, 44]. Genera that include common bacterial PRDC pathogens, namely Streptococcus, Haemophilus, Pasteurella, and Bordetella, were found to be more relatively abundant in BAL samples from diseased animals, often in combination with a reduction of beneficial genera (e.g. Lactococcus and Lactobacillus) [44]. PRDC is also associated with changes in the composition of the URT microbiota, as evidenced by the higher abundance of Moraxella, Veillonella, and Porphyromonas in the oropharynx of PRDC-affected pigs [41]. As observed in human patients with respiratory disease [52-54], low species richness and diversity in the URT was associated with piglets affected by Glässer's disease [35], a systemic disease often associated with pneumonia. Metataxonomic profiling of the microbiome of porcine lungs with and without macroscopic lesions revealed that microbial diversity was lower in porcine lungs with severe lesions than in healthy or moderately affected lungs [43]. At the phylum level, a significant reduction in the relative abundance of Firmicutes and Actinobacteria was observed in lungs with severe lesions compared to healthy lungs, which was associated with an increase of Mycoplasma and a reduction of Lactobacillus and Streptococcus at the genus level [43].

The porcine URT microbiome has been widely investigated with a focus on the spread of methicillin-resistant Staphylococcus aureus (MRSA), an emerging zoonotic pathogen in pig farming [55]. In a longitudinal study of S. aureus carriage in Danish pig farms, 20 taxa were associated with non-carriage of $S$. aureus in the nasal microbiome, including species from the Leuconostocaceae and Lachnospiraceae families [36]. In another study, MRSA colonization of the nasal cavity was inversely correlated to the occurrence of Streptococcus spp., suggesting a possible antagonism between streptococci and MRSA [37]. Concerns over the increasing emergence of antibiotic-resistant bacteria have prompted efforts to identify alternatives to antimicrobials in animal production, such as probiotics. Members of the Lactobacillus genus have been widely proposed as probiotic agents thank to their ability to increase natural killer cell activity, reduce proinflammatory cytokine production and protect biological niches [13]. Although the effect of Lactobacillus spp. on the respiratory tract of pigs remains unclear, a significant reduction in the relative abundance of Lactobacillus was observed in both the oropharynx and lungs of PRDC-affected pigs, as compared to healthy animals [41, 43, 44]. Taken together, this evidence supports the hypothesis that Lactobacillus 
spp. could exert a protective role against respiratory pathogens.

Very little is known about the relationship of the respiratory microbiome with pig productivity. A single study suggested that the rate of average daily gain of piglets could be associated with a characteristic oropharyngeal microbial signature and that manipulating the oropharyngeal microbiota in pre-weaned piglets could influence weight gain [56]. In addition, several reports have shown the importance of the gut microbiome in pig productivity through its effects on digestion, feed efficiency and immune stimulation [57]. These studies suggest that there might be close relationship between the microbial community colonizing different body sites, including the respiratory tract, and animal's weight gain and other productivity parameters.

\section{Methodological study limitations}

Despite the advancement of the sequencing and bioinformatics tools, unique technical challenges and pitfalls bias the results of respiratory microbiome studies. First, sequencing target and strategy may lead to discrepancies in the abundance of some taxa [58-60]. Among these, differences in the $i$ ) 16S rRNA gene variable region targeted, $i$ i) primers employed, iii) length of the reads produced by the sequencing platforms, $i v$ ) data processing software and v) reference databases are among the major methodological problem with the largest impact on the outcomes of the studies [58, 61]. Notably, the reviewed studies showed a remarkable variability in the selection of $16 \mathrm{~S}$ rRNA region, sequencing platform and bioinformatic tools for analyses (Table 1). Therefore, standardisation of protocols for metagenomic profiling is strongly encouraged.

Specimen collection from both the URT and LRT plays a critical role in microbiome studies. Nasal and tonsil swabs are the most frequent samples examined in URT microbiome studies (Table 1). Nasal sampling has the advantages of being non-invasive and minimising distress, whereas non-invasive tonsil and larynx swabs yielded similar results with respect to tissue specimens, eliminating the need to euthanize animals to collect the tissue [38, 42]. The inherent difficulty in sampling the LRT and the remarkably low bacterial burden in healthy lungs are some of the technical challenges hampering LRT microbiome research $[62,63]$. In pigs, BAL samples of healthy animals have an average bacterial load of $10^{4}-$ $10^{5} \mathrm{CFU} / \mathrm{ml}$, although it has been reported that most of the detectable bacterial DNA in the lung parenchyma is DNase I sensitive and corresponds to dead bacteria [64]. In a study by Siqueira et al. (2017) due to difficulties in obtaining large quantities of DNA from individual lungs, the material retrieved from 20 lungs with suggestive enzootic pneumonia signs and from 20 lungs without macroscopic signs was pooled [46]. However, while pooling samples can be helpful to overcome the issues related to low DNA yield in BAL samples, it does not allow for the assessment of individual variation [65].

Although contamination of BAL samples during passage of the endoscope through the URT is unavoidable, previous studies in pigs and humans have shown that this has a negligible effect on respiratory acquired through bronchoscopy [5, 64]. Nevertheless, transbronchial BAL collection should be preferred to transoral [33]. Tracheobronchial swabbing is a less invasive alternative to BAL for LRT specimen collection that is well established in pig clinical practice, especially for detection of PRDC pathogens $[66,67]$. Collection of tracheobronchial swabs does not require anaesthesia, which is necessary prior to BAL sampling. Further studies are warranted to evaluate the use of tracheobronchial swabs as proxies for lung microbiome studies.

Contrary to cattle studies, in which BAL was mainly performed by trans-tracheal aspiration on mildly sedated animals $[68,69]$, previous studies in pigs used BAL samples collected immediately after slaughter, with consequent risks of bacterial contamination via aspiration of scalding water. Scalding operations may affect the lung microbiome composition due to ingestion of water in scalding tanks (at $70^{\circ} \mathrm{C}$ ), which is usually reused and becomes contaminated by bacterial DNA from the skin of dead animals [70]. Therefore, collection of post-mortem BAL at slaughter poses serious risks of contamination.

Lastly, contamination through handling and processing of samples is considered another major pitfall in respiratory microbiome studies [71]. Most studies investigating the porcine airway microbiome failed to include positive (i.e. mock communities) and negative (i.e. extraction control and PCR blank) control samples (Table 1). This omission, paired with the investigation of relatively low biomass microbiomes, provides a source of uncertainty in the results, which are potentially indistinguishable from contaminations. This is why inclusion of negative controls for sampling, DNA extraction and sequencing, and positive controls for DNA extraction and sequencing have been proposed as standards in microbiome research [72].

\section{Conclusions and future perspectives}

Recent technological advancements have allowed us to appreciate differences in microbiome composition between different URT sites (e.g. nasal cavity versus tonsils and oropharynx), and highlight associations between URT microbial structure and the onset of respiratory disease. As with humans and other animal species, appears that the respiratory microbiome of healthy pigs is characterized by higher microbial richness and evenness compared to diseased pigs, suggesting that an imbalance 
in the microbial composition plays a key role in susceptibility to PRDC. An unstable microbiota seems to enhance colonization of the URT epithelial surfaces by opportunistic pathogenic bacteria, which can further progress into the LRT causing lung disease.

Understanding the complex interactions and relationships of the pig respiratory microbiome with health and disease is however at its early stage. More research is needed to clarify the interaction between commensal microorganisms and opportunistic pathogens, including bacteria, viruses and fungi residing in the airway, and their role in the development of PRDC. As the current knowledge of the role of the microbiome in PRDC is based on comparisons of healthy and disease lungs, longitudinal studies are warranted to determine the ecological changes in the lung microbiota during disease development, and how such changes relate to antimicrobial exposure in diseased pigs. The vast majority of studies on the porcine respiratory microbiome focused on the URT bacterial community alone. Hence, further studies investigating both the URT and LRT microbial structure in pigs are warranted to clarify how and to what extent the lung microbiota overlaps with that inhabiting the upper airways. Moreover, in most studies metataxonomic profiling was resolved only at the genus level, possibly due to the choice of the 16S rRNA gene region and to incomplete $16 \mathrm{~S}$ reference database. Therefore, data at the species level are required to magnify the structure of the respiratory microbial community in pigs and its relationship with disease.

Viral and fungal communities play a key role in the microbiome of the human and animal respiratory tract. Nevertheless, studies investigating the pig respiratory virome are scarce [47, 48], whereas to the best of our knowledge, studies of mycobiome of the porcine respiratory tract are completely lacking. Expanding the community profiling to non-bacterial members of the pig respiratory microbiome (e.g. viruses, phages, and fungi) could generate an accurate snapshot of the entire microbial community and add further insights on how these members interact with the respiratory bacterial microbiota. Such issues could be solved by shotgun sequencing, although results might be hampered by low quantities of biomass and DNA, especially in LRT samples. Finally, appropriate specimen collection, uniform laboratory practice (selection of the 16S rRNA region, sequencing platform, and data processing software) and inclusion of sequencing controls should be envisioned in future studies addressing the porcine respiratory microbiome.

\section{Abbreviations}

BAL: Bronchoalveolar lavage; LRT: Lower respiratory tract; MRSA: Methicillinresistant Staphylococcus aureus; PRDC: Porcine respiratory disease complex; URT: Upper respiratory tract

\section{Acknowledgements}

Debby Bogaert and Luca Guardabassi are members of ESCMID Study Group for host and microbiota interaction (ESGHAMI).

\section{Authors' contributions}

LG conceived the study and provided funding. MP reviewed the literature and drafted the manuscript. LG, CEG and DB revised the manuscript. All authors revised and approved the final manuscript.

\section{Funding}

This work was funded by the Bloomsbury SET programme (https://eur02. safelinks.protection.outlook.com/?url=http\%3A\%2F\%2Fwww.bloomsburyset. org.uk\%2F\&data=04\%7C01\%7Clg\%40sund.ku.dk\%7Cd7ee4552a8ac49772bd2 08d8a1e00996\%7Ca3927f91cda14696af898c9f1 ceffa91\%7C0\%7C0\%7C63743 7330901640963\%7CUnknown\%7CTWFpbGZsb3d8eyJWIjoiMC4 wLjAwMDAiLCJQljoiV2luMzliLCJBTil6lk1 haWwiLCJXVCI6Mn0\%3D\%7C1 000\&sdata=VZcMCSbRqYWwMJeABA2OafIKK9TonMPOFEfQuHeidQk\%3 D\&reserved=0), supported by Research England's Connecting Capabilities Fund.

Availability of data and materials

Not applicable.

Ethics approval and consent to participate

Not applicable.

\section{Consent for publication}

Not applicable.

\section{Competing interests}

The authors declare that they have no competing interests.

\section{Author details}

'Department of Veterinary and Animal Sciences, University of Copenhagen, Frederiksberg, Denmark. ${ }^{2}$ Department of Science, Roma Tre University, Rome, Italy. ${ }^{3}$ Center for Inflammation Research, University of Edinburgh, Edinburgh, UK. ${ }^{4}$ Department of Pathobiology \& Population Sciences, Royal Veterinary College, United Kingdom, Hawkhead Lane, North Mymms, Hatfield, Herts AL9 7TA, UK.

Received: 5 November 2020 Accepted: 16 December 2020

Published online: 08 January 2021

References

1. Chiu CY, Miller SA. Clinical metagenomics. Nat Rev Genet. 2019;20:341-55.

2. Gill SR, Pop M, DeBoy RT, Eckburg PB, Turnbaugh PJ, Samuel BS, et al. Metagenomic analysis of the human distal gut microbiome. Science. 2006; 312:1355-9.

3. Turnbaugh PJ, Ley RE, Mahowald MA, Magrini V, Mardis ER, Gordon II. An obesity-associated gut microbiome with increased capacity for energy harvest. Nature. 2006;444:1027-31.

4. Turnbaugh PJ, Hamady M, Yatsunenko T, Cantarel BL, Duncan A, Ley RE, et al. A core gut microbiome in obese and lean twins. Nature. 2009;457: 480-4.

5. Dickson RP, Erb-Downward JR, Freeman CM, McCloskey L, Falkowski NR, Huffnagle GB, et al. Bacterial topography of the healthy human lower respiratory tract. mBio. 2017;8:e02287-16.

6. McMullen C, Alexander TW, Léguillette R, Workentine M, Timsit E. Topography of the respiratory tract bacterial microbiota in cattle. Microbiome. 2020;8. https://doi.org/10.1186/s40168-020-00869-y.

7. Brockmeier S, Halbur P, Thacker EL. Porcine respiratory disease complex. In: Brogden K, Guthmiller J, editors. Polymicrobial diseases. Washington, DC: ASM Press; 2002. p. 231-58.

8. Hansen MS, Pors SE, Jensen HE, Bille-Hansen V, Bisgaard M, Flachs EM, et al. An investigation of the pathology and pathogens associated with porcine respiratory disease complex in Denmark. J Comp Pathol. 2010;143:120-31.

9. Holt HR, Alarcon P, Velasova M, Pfeiffer DU, Wieland B. BPEX pig health scheme: a useful monitoring system for respiratory disease control in pig farms? BMC Vet Res. 2011;7:82.

10. United States Department of Agriculture (USDA). Swine 2012 part I: baseline reference of swine health and management in the United States, 2012. Fort 
Collins: USDA-APHIS-VS, CEAH; 2015. https://www.aphis.usda.gov/animal_ health/nahms/swine/downloads/swine2012/Swine2012_dr_Partl.pdf (Accessed 26 Oct 2020).

11. Opriessnig T, Giménez-Lirola LG, Halbur PG. Polymicrobial respiratory disease in pigs. Anim Health Res Rev. 2011;12:133-48.

12. García N, Fernández-Garayzábal JF, Goyache J, Domínguez L, Vela Al. Associations between biovar and virulence factor genes in Pasteurella multocida isolates from pigs in Spain. Vet Rec. 2011;169:362.

13. Niederwerder MC. Role of the microbiome in swine respiratory disease. Vet Microbiol. 2017;209:97-106.

14. Krejci J, Nechvatalova K, Blahutkova M, Faldyna M. The respiratory tract in pigs and its immune system: a review. Vet Med. 2013;58:206-20.

15. Ackermann M. Respiratory tract. In: Biology of the domestic pig; 2001. p 502-32.

16. Funkhouser $L$, Bordenstein SR. Mom knows best: the universality of maternal microbial transmission. PLoS Biol. 2013;11:e1001631.

17. Wang M, Radlowski EC, Monaco MH, Fahey GC, Gaskins HR, Donovan SM. Mode of delivery and early nutrition modulate microbial colonization and fermentation products in neonatal piglets. J Nutr. 2013;143:795-803.

18. Pena Cortes LC, LeVeque RM, Funk J, Marsh TL, Mulks MH. Development of the tonsillar microbiome in pigs from newborn through weaning. BMC Microbiol. 2018;18:35.

19. Koppen IJN, Bosch AATM, Sanders EAM, van Houten MA, Bogaert D. The respiratory microbiota during health and disease: a paediatric perspective. Pneumonia. 2015;6:90-100

20. Bosch AATM, Levin E, van Houten MA, Hasrat R, Kalkman G, Biesbroek G, et al. Development of upper respiratory tract microbiota in infancy is affected by mode of delivery. EBioMedicine. 2016;9:336-45.

21. Slifierz MJ, Friendship RM, Weese JS. Longitudinal study of the early-life fecal and nasal microbiotas of the domestic pig. BMC Microbiol. 2015;15:184.

22. Zhang L, Mu C, He X, Su Y, Mao S, Zhang J, et al. Effects of dietary fibre source on microbiota composition in the large intestine of suckling piglets. FEMS Microbiol Lett. 2016;363:fnw138.

23. Pena Cortes LC, LeVeque RM, Funk JA, Marsh TL, Mulks MH. Development of the tonsil microbiome in pigs and effects of stress on the microbiome. Front Vet Sci. 2018:5:220.

24. Weese JS, Slifierz M, Jalali M, Friendship R. Evaluation of the nasal microbiota in slaughter-age pigs and the impact on nasal methicillinresistant Staphylococcus aureus (MRSA) carriage. BMC Vet Res. 2014;10:69.

25. Megahed A, Zeineldin M, Evans K, Maradiaga N, Blair B, Aldridge B, et al. Impacts of environmental complexity on respiratory and gut microbiome community structure and diversity in growing pigs. Sci Rep. 2019;9:13773.

26. Wang T, He Q, Yao W, Shao Y, Li J, Huang F. The variation of nasal microbiota caused by low levels of gaseous ammonia exposure in growing pigs. Front Microbiol. 2019;10:1083.

27. Michiels A, Piepers S, Ulens T, Van Ransbeeck N, Del Pozo SR, Sierens A, et al. Impact of particulate matter and ammonia on average daily weight gain, mortality and lung lesions in pigs. Prev Vet Med. 2015;121:99-107.

28. Lhermie G, La Ragione RM, Weese JS, Olsen JE, Christensen JP, Guardabassi L. Indications for the use of highest priority critically important antimicrobials in the veterinary sector. J Antimicrob Chemother. 2020;75:1671-80.

29. Zeineldin M, Aldridge B, Blair B, Kancer K, Lowe J. Microbial shifts in the swine nasal microbiota in response to parenteral antimicrobial administration. Microb Pathog. 2018;121:210-7.

30. Mou KT, Allen HK, Alt DP, Trachsel J, Hau SJ, Coetzee JF, et al. Shifts in the nasal microbiota of swine in response to different dosing regimens of oxytetracycline administration. Vet Microbiol. 2019;108386:108386.

31. Correa-Fiz F, Gonçalves dos Santos JM, Illas F, Aragon V. Antimicrobial removal on piglets promotes health and higher bacterial diversity in the nasal microbiota. Sci Rep. 2019;9:6545.

32. Man WH, de Steenhuiisen Piters WAA, Bogaert D. The microbiota of the respiratory tract: gatekeeper to respiratory health. Nat Rev Microbiol. 2017; 15:259-70.

33. Nicola I, Cerutti F, Grego E, Bertone I, Gianella P, D'Angelo A, et al. Characterization of the upper and lower respiratory tract microbiota in Piedmontese calves. Microbiome. 2017;5:152.

34. Zeineldin MM, Lowe JF, Grimmer ED, de Godoy MRC, Ghanem MM, Abd ElRaof YM, et al. Relationship between nasopharyngeal and bronchoalveolar microbial communities in clinically healthy feedlot cattle. BMC Microbiol. 2017;17:138
35. Correa-Fiz F, Fraile L, Aragon V. Piglet nasal microbiota at weaning may influence the development of Glässer's disease during the rearing period. BMC Genomics. 2016;17:404.

36. Espinosa-Gongora C, Larsen N, Schønning K, Fredholm M, Guardabassi L. Differential analysis of the nasal microbiome of pig carriers or non-carriers of Staphylococcus aureus. PLoS One. 2016;11:e0160331.

37. Strube ML, Hansen JE, Rasmussen S, Pedersen K. A detailed investigation of the porcine skin and nose microbiome using universal and Staphylococcus specific primers. Sci Rep. 2018;8:12751.

38. Lowe BA, Marsh TL, Isaacs-Cosgrove N, Kirkwood RN, Kiupel M, Mulks MH. Defining the "core microbiome" of the microbial communities in the tonsils of healthy pigs. BMC Microbiol. 2012;12:20.

39. Holman DB, Bearson BL, Allen HK, Shippy DC, Loving CL, Kerr BJ, et al. Chlortetracycline enhances tonsil colonization and fecal shedding of multidrug-resistant Salmonella enterica Serovar Typhimurium DT104 without major alterations to the porcine tonsillar and intestinal microbiota. Appl Environ Microbiol. 2019;85:e02354-18.

40. Prevaes SMPJ, Piters WAA d S, Groot KM, Janssens HM, Tramper-Stranders GA, Chu MLJN, et al. Concordance between upper and lower airway microbiota in infants with cystic fibrosis. Eur Respir J. 2017;49:1602235.

41. Wang Q, Cai R, Huang A, Wang X, Qu W, Shi L, et al. Comparison of oropharyngeal microbiota in healthy piglets and piglets with respiratory disease. Front Microbiol. 2018;9:3218.

42. Hanshew AS, Jetté ME, Tadayon S, Thibeault SL. A comparison of sampling methods for examining the laryngeal microbiome. PLoS One. 2017;12: e0174765.

43. Huang T, Zhang M, Tong X, Chen J, Yan G, Fang S, et al. Microbial communities in swine lungs and their association with lung lesions. J Microbial Biotechnol. 2019;12:289-304.

44. Li Z, Wang X, Di D, Pan R, Gao Y, Xiao C, et al. Comparative analysis of the pulmonary microbiome in healthy and diseased pigs. Mol Genet Genomics. 2020. https://doi.org/10.1007/s00438-020-01722-5.

45. Jiang $\mathrm{N}$, Liu H, Wang P, Huang J, Han H, Wang Q. Illumina MiSeq sequencing investigation of microbiota in bronchoalveolar lavage fluid and cecum of the swine infected with PRRSV. Curr Microbiol. 2019;76:222-30.

46. Siqueira FM, Pérez-Wohlfeil E, Carvalho FM, Trelles O, Schrank IS, Vasconcelos ATR, et al. Microbiome overview in swine lungs. PLoS One. 2017:12:e0181503.

47. Blomström A-L, Ye X, Fossum C, Wallgren P, Berg M. Characterisation of the virome of tonsils from conventional pigs and from specific pathogen-free pigs. Viruses. 2018;10:382.

48. Qin S, Ruan W, Yue H, Tang C, Zhou K, Zhang B. Viral communities associated with porcine respiratory disease complex in intensive commercial farms in Sichuan province, China. Sci Rep. 2018;8:13341.

49. Huang YJ, Sethi S, Murphy T, Nariya S, Boushey HA, Lynch SV. Airway microbiome dynamics in exacerbations of chronic obstructive pulmonary disease. J Clin Microbiol. 2014;52:2813-23.

50. Coburn B, Wang PW, Diaz Caballero J, Clark ST, Brahma V, Donaldson S, et al. Lung microbiota across age and disease stage in cystic fibrosis. Sci Rep. 2015;5:10241

51. Zeineldin M, Lowe J, Aldridge B. Contribution of the mucosal microbiota to bovine respiratory health. Trends Microbiol. 2019;27:753-70.

52. Pettigrew MM, Laufer AS, Gent JF, Kong Y, Fennie KP, Metlay JP. Upper respiratory tract microbial communities, acute otitis media pathogens, and antibiotic use in healthy and sick children. Appl Environ Microbiol. 2012;78: 6262-70.

53. Zhao J, Schloss PD, Kalikin LM, Carmody LA, Foster BK, Petrosino JF, et al. Decade-long bacterial community dynamics in cystic fibrosis airways. Proc Natl Acad Sci U S A. 2012;109:5809-14.

54. Watson RL, de Koff EM, Bogaert D. Characterising the respiratory microbiome. Eur Respir J. 2018:53:1801711.

55. Guardabassi L, Larsen J, Weese JS, Butaye P, Battisti A, Kluytmans J, et al. Public health impact and antimicrobial selection of meticillin-resistant staphylococci in animals. J Glob Antimicrob Resist. 2013;1:55-62.

56. Bugenyi AW, Cho H-S, Heo J. Association between oropharyngeal microbiome and weight gain in piglets during pre and post weaning life. J Anim Sci Technol. 2020;62:247-62.

57. Knecht D, Cholewińska P, Jankowska-Mąkosa A, Czyż K. Development of swine's digestive tract microbiota and its relation to production indices-a review. Animals (Basel). 2020:10:527. 
58. Clooney AG, Fouhy F, Sleator RD, O'Driscoll A, Stanton C, Cotter PD, et al. Comparing apples and oranges?: next generation sequencing and its impact on microbiome analysis. PLoS One. 2016;11:e0148028.

59. Yang B, Wang Y, Qian P-Y. Sensitivity and correlation of hypervariable regions in 165 rRNA genes in phylogenetic analysis. BMC Bioinformatics. 2016;17:135

60. Bukin YS, Galachyants YP, Morozov IV, Bukin SV, Zakharenko AS, Zemskaya TI. The effect of 165 rRNA region choice on bacterial community metabarcoding results. Scientific Data. 2019;6:190007.

61. Balvočiūtè M, Huson DH. SILVA, RDP, Greengenes, NCBI and OTT — how do these taxonomies compare? BMC Genomics. 2017;18:114.

62. Charlson ES, Bittinger K, Haas AR, Fitzgerald AS, Frank I, Yadav A, et al. Topographical continuity of bacterial populations in the healthy human respiratory tract. Am J Respir Crit Care Med. 2011;184:957-63.

63. Twigg HL, Morris A, Ghedin E, Curtis JL, Huffnagle GB, Crothers K, et al. Use of bronchoalveolar lavage to assess the respiratory microbiome: signal in the noise. Lancet Respir Med. 2013;1:354-6.

64. Pezzulo AA, Kelly PH, Nassar BS, Rutland CJ, Gansemer ND, Dohrn CL, et al. Abundant DNase I-sensitive bacterial DNA in healthy porcine lungs and its implications for the lung microbiome. Appl Environ Microbiol. 2013;79. 5936-41.

65. Caudill SP. Characterizing populations of individuals using pooled samples. Expo Sci Environ Epidemiol. 2010;20:29-37.

66. Fablet C, Marois C, Kobisch M, Madec F, Rose N. Estimation of the sensitivity of four sampling methods for Mycoplasma hyopneumoniae detection in live pigs using a Bayesian approach. Vet Microbiol. 2010;143:238-45.

67. Hou D, Bi Y, Sun H, Yang J, Fu G, Sun Y, et al. Identification of swine influenza a virus and Stenotrophomonas maltophilia co-infection in Chinese pigs. Virol J. 2012;9:169

68. Stroebel C, Alexander T, Workentine ML, Timsit E. Effects of transportation to and co-mingling at an auction market on nasopharyngeal and tracheal bacterial communities of recently weaned beef cattle. Vet Microbiol. 2018; 223:126-33.

69. Timsit E, Workentine M, van der Meer F, Alexander T. Distinct bacterial metacommunities inhabit the upper and lower respiratory tracts of healthy feedlot cattle and those diagnosed with bronchopneumonia. Vet Microbiol. 2018;221:105-13

70. Bolton DJ, Pearce R, Sheridan JJ, McDowell DA, Blair IS. Decontamination of pork carcasses during scalding and the prevention of salmonella crosscontamination. J Appl Microbiol. 2003;94:1036-42.

71. Salter SJ, Cox MJ, Turek EM, Calus ST, Cookson WO, Moffatt MF, et al. Reagent and laboratory contamination can critically impact sequence-based microbiome analyses. BMC Biol. 2014;12:87.

72. Hornung BVH, Zwittink RD, Kuijper EJ. Issues and current standards of controls in microbiome research. FEMS Microbiol Ecol. 2019;95.

\section{Publisher's Note}

Springer Nature remains neutral with regard to jurisdictional claims in published maps and institutional affiliations.

Ready to submit your research? Choose BMC and benefit from:

- fast, convenient online submission

- thorough peer review by experienced researchers in your field

- rapid publication on acceptance

- support for research data, including large and complex data types

- gold Open Access which fosters wider collaboration and increased citations

- maximum visibility for your research: over $100 \mathrm{M}$ website views per year

At $\mathrm{BMC}$, research is always in progress.

Learn more biomedcentral.com/submissions 